\title{
Deteksi Tungkai Bayi Pada Image Sequence Berbasis Vector Depth Estimation
}

\author{
Faisal Lutfi Afriansyah', Niyalatul Muna ${ }^{2}$ \\ ${ }^{1}$ Jurusan Teknologi Informasi, ${ }^{2}$ Jurusan Kesehatan, Politeknik Negeri Jember \\ ${ }^{1}$ faisal.lutfi@polije.ac.id, ${ }^{2}$ niyalatul@polije.ac.id
}

\begin{abstract}
Abstrak
Kamera secara umum tidak terkalibrasi dan tidak memilik fitur untuk menghitung vector depth (kedalaman vector). Karena untuk mendeteksi dan menemukan gerakan tungkai dibutuhkan nilai depth untuk mengenali fitur berupa nilai besaran magnitude dan besaran motion vector, tidak hanya berdasarkan parameter $x$ dan $y$ namun juga $z$ sehingga dengan adanya tambahan parameter memudahkan dalam melakukan analisa gerakan terhadap sumbu gerakan dan motion vectornya. Paper ini membahas tentang metode untuk mendeteksi besaran magnitude dan besaran motion vector sebagai fitur gerakan tungkai pada bayi pasca operasi dengan mengurutkan gambar image sequence kemudian menemukan point of transfer motion frame destination dari bingkai frame reference dengan memperoleh depth (kedalaman vector) menggunakan fundamental matrix dari hasil generate motion vector. Metode ini direkomendasikan karena dapat dijadikan sebagai parameter untuk menghitung nilai fitur magnitude dan besaran motion vector dari inputan berupa image sequence dengan menghitung parameter intrinsic sehingga dapat dilakukan deteksi tungkai bayi pasca operasi. Penelitian ini menghasilkan nilai pengujian residual error sebesar $1,82 \times 10^{-07}$. Hasil dari nilai fitur yang diperoleh dijadikan parameter untuk deteksi tungkai bayi dengan melakukan pengelompokkan (cluster) menggunakan K-Means. Hasil yang diperoleh terdiri dari cluster 0 dan 1, sebesar 36\% dan 64\% dengan presentase Incorrectly clustered instances $14.8936 \%$.
\end{abstract}

Kata kunci : image sequence, deteksi tungkai, uncalibrated camera, vector depth estimation.

\section{Pendahuluan}

Penanganan nyeri pada bayi menyisakan permasalahan yang belum memiliki penyelesaian seperti pada penanganan nyeri pada penderita dewasa,khususnya dalam hal diagnosis nyeri belum ada gold standard seperti yang sudah diakui untuk penderita dewasa yaitu Visual Analog Scale (VAS). Usaha memperbaiki sarana diagnosis nyeri bayi sudah diusahakan dengan membuat sistem penilaian dari parameter perilaku dan parameter fisiologis, namun pelaksanaan dan penggunaanya di klinik masih rendah oleh karena berbagai alasan. Tanpa diagnosis yang tepat terapi nyeri tidak bisa dinilai efektivitasnya dan potensi penyulit akibat pemberian terapi nyeri juga meningkat.

Nyeri adalah pengalaman subjektif dan tidak ada tes objektif untuk mengukurnya, IASP (Asosiasi Internasional untuk Studi Nyeri) memutuskan laporan diri pasien sebagai standar emas penilaian nyeri. Bayi tidak dapat memberikan laporan sendiri tentang rasa sakit secara lisan.

Gerakan bayi adalah alat komunikasi yang digunakan untuk berkomunikasi dengan orang lain, tangisan digunakan untuk komunikasi oleh bayi karena bayi tidak dapat mengekspresikan kebutuhan dan keinginan mereka melalui bahasa (David P. Snow, 2017). Meskipun mereka bisa memberikan lebih banyak tanda seperti menendang kaki, melambaikan tangan dan menggerakkan kepala. Ada beberapa makna tangisan, dan gerakan kaki dan tangan pada bayi menunjukkan bahwa menjadi lapar, popok basah, terlalu panas atau terlalu dingin, pakaian yang terlalu ketat, rasa sakit dan banyak hal lainnya.

Bagi orang lain akan kesulitan membedakan gerakan dan tangisan bayi, tetapi bagi ibu bayi, maksud tangisan dan gerakan bayi adalah hal yang mudah dipahami maksudnya (Hernández-González et al.,2016), (Hannah. F. Rasmussen et al.,2016) karena gerakan dan tangisan bayi memiliki pola yang memberikan arti yang bisa dipahami oleh ibu dari bayi tersebut dan orang terdekat.Ini adalah latar belakang penelitian ini, jika seorang ibu dapat memahami dan mengenali arti tangisan dan gerakan pada bayi, itu berarti ada pola bayi yang dapat diproses dan dapat digunakan sebagai informasi, jika dapat dikenali dan dipahami oleh ibu dari bayi (Hina Simonnet et al.,2014), maka secara logis dimungkinkan juga bagi komputer dengan bantuan machine learning untuk dapat melakukan analisa.

Sistem pengenalan gerakan bayi pada mesin dapat diamati melalui kamera. Hasil tangkapan dari kamera ditampilkan dan diolah dalam bentu image sequence. Masalah yang paling umum adalah kamera yang digunakan tidak terkalibrasi. Beberapa penelitian telah membahas deteksi objek dengan 
kamera, namun tidak secara spesifik tentang pergerakan tungkai pada bayi.

Penelitian sebelumnya tentang deteksi gerak untuk orang dewasa (Tongyang Sun et al.,2016), pada kaki manusia dengan menggunakan alat LPMS (Life performance analysis motion sensor) adalah alat yang ditempelkan pada pad yang memiliki sensor sistem koordinat $\mathrm{X}, \mathrm{Y}$, dan Z. kemudian penelitian tentang penyakit neonatal menggunakan pemrosesan video berdasarkan gerakan untuk mendeteksi kejang dan penyakit apnea (Luca Cattani et al.,2016) data diperoleh dari beberapa sensor video yang ditempatkan di sekitar pasien, mengekstraksi sinyal gerakan yang relevan dan diperkirakan menggunakan kriteria Maximum Likelihood (ML). Sedangkan untuk penelitian tentang pergerakan kaki bayi berbasis vector depth estimation menggunakan kamera belum pernah ada penelitian sebelumnya.

Pada penelitian sebelumnya telah dilakukan penelitian sistem untuk mengenali aktivitas bayi pasca operasi berbasis FLACC (Wajah, Kaki, Aktivitas, Menangis, Penghiburan), skor 0 diberikan jika bayi bergerak dengan mudah, skor 1 jika bayi menggeliat, dan skor 2 jika bayi tersentak dengan mengamati ciri-ciri gerakan. Dalam FLACC, aktivitas merupakan salah satu dari lima parameter untuk mengidentifikasi tingkat nyeri bayi. Menggunakan algoritma pencocokan blok dengan penambahan deret Taylor untuk menghasilkan nilai dengan akurasi gerak subpiksel dari frame referensi ke frame saat ini dalam bentuk vektor gerak. Video telah diverifikasi oleh dokter dan perawat menggunakan hormon kortisol dengan pengukuran FLACC (Faisal Lutfi et al.,2017).

Hasil penelitian menunjukkan klasifikasi menggunakan SVM dapat mendeteksi aktivitas bayi bergerak dengan mudah, menggeliat, dan menghentak sebesar 90.4762\%. (Faisal Lutfi et al.,2017).

Paper ini mengembangkan sistem untuk mengubah motion vector video dua dimensi $(X, Y)$ menjadi tiga dimensi $(X, Y, Z)$ berbasis depth estimation, dengan tujuan untuk bisa mendapatkan nilai fitur ciri dari tungkai bayi sehingga bisa digunakan untuk melihat besaran magintude dan besaran motion vector untuk melihat tingkat besaran gerakan sebagai salah satu parameter pengukuran nyeri pada bayi pasca operasi. Langkah pertama adalah menemukan vektor gerak dari data video, kemudian memperkirakan fundamental matrix dari vektor gerak pada data video, kemudian mencari matriks kamera dari fundamental matriks dan menggunakan triangulasi untuk menentukan depth objek kaki yang dideteksi,.

\section{Metode Yang Diusulkan}

Penelitian ini mengusulkan metode pengolahan data dengan melakukan langkah-langkah pada Gambar 1. Tahap pertama yang dilakukan akuisisi video bayi pasca operasi, kemudian dilakukan proses prepocessing image sequence dengan mencari motion vector dari setiap pergerakan bayi. Sampel yang diambil dalam penelitian terdiri dari bayi yang bergerak secara terus menerus (menggeliat) dan bayi yang tenang.

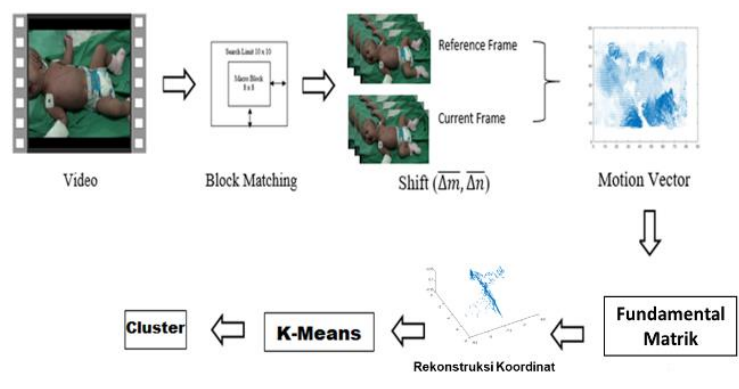

Gambar 1. Block Diagram Deteksi Tungkai bayi

Setelah didapat nilai pergerakan dari setiap frame dilakukan perhitungan matrik fundamental. Setelah itu dilakukan perhitungan hingga menemukan matriks proyeksi kamera dan dilakukan rekonstruksi. Titik-titik yang direkonstruksi setiap sampelnya dideteksi tungkai bayi dari image sequence pada sampel bayi menggeliat, untuk mengetahui persebaran nilai dari fitur tungkai bayi kemudian dilakukan pengelompokkan berdasarkan sampel data dengan menggunakan k-means. Nantinya hasil ekstraksi akan digunakan untuk menentukan fitur tungkai dengan melihat besaran magnitude dan nilai besaran motion estimation.

\subsection{Motion Vector}

Motion vector adalah gerakan yang menunjukkan perpindahan titik antara frame saat ini dengan frame referensi. Dari motion vector yang diperoleh, akan terlihat pergerakan titik yang terjadi antar frame yang diamati (Eko Mulyanto et al.,2013). Besarnya motion vector akan terlihat elemen temporal korelasi dalam bentuk gerakan objek, hal ini untuk membedakan anatar perubahan point of view atau karena adanya pergerakan pada kamera yang dapat dilihat pada Gambar.2.

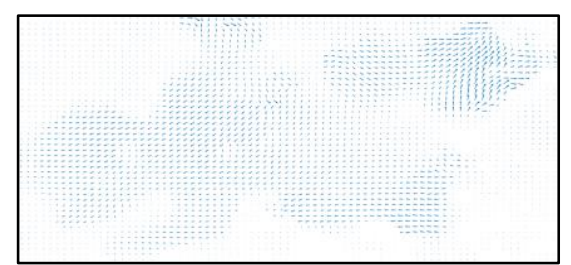

Gambar 2. Motion Vector bayi ukuran blok 8x8

Dengan membandingkan titik-titik fitur dengan titiktitik fitur dari frame sebelumnya, pasangan yang cocok dapat dipilih, dan pergerakan setiap titik dari satu frame ke frame lainnya dihitung menggunakan motion vector (Andrej Fogelton,2016). 
Jika posisi blok target dan blok sebelumnya sama, maka vektor geraknya adalah nol. Vektor gerak ini yang menunjukkan pergeseran pada blok blok antar frame. Ketika encode setiap blok dari suatu frame yang dapat diprediksi, gerakan vektor yang menunjukkan posisi blok yang cocok dengan frame referensi, maka dikodifikasikan dalam blok target itu sendiri.

Motion Estimation merupakan teknik kompresi yang memprediksi Interframe sebuah frame dari frame sebelumnya (frame referensi), dengan memperkirakan pergerakan blok antar frame. Frame dibagi menjadi blok yang berurutan. Setiap blok dibandingkan dengan blok berukuran sama, frame sebelumnya dengan teknik block matching.

Dengan menunjukkan perpindahan, MV mampu menggambarkan perpindahan objek pada frame. Performa MV yang handal diaplikasikan menjadi teknik kompresi video yaitu motion compensation (MC) yang, populer dan digunakan hampir pada semua standar pengkodean video seperti pada seri-seri MPEG. MC menghasilkan transformasi antar frame menggunakan MV yang mengurangi redundansi antar frame dan meningkatkan efisiensi kompresi video. MV dapat diperoleh melalui estimasi menggunakan blockmatching algorithm (BMA).

Block-matching algorithm (BMA) algoritme adalah pencarian lokasi suatu macroblock (MB) dengan ukuran tertentu yang paling sesuai pada frame lainnya berdasarkan suatu kriteria jarak pencarian (Luca Cattani et al.,2016). MB adalah daerah frame yang dikodekan sebagai sebuah unit. MB biasanya adalah sekelompok piksel yang membentuk persegi dengan ukuran sisi persegi tertentu. BMA dapat menghasilkan MV pada rangkaian frame video dengan membagi CFI kedalam sejumlah MB seperti pada Error! Reference source not found. dan kemudian mencari daerah pada RFI yang memiliki kesesuaian terbaik dengan MB CFI

Block matching target dengan kandidat blok di area pencarian dilakukan dengan magnitude tertentu, yaitu pergeseran yang signifikan dalam blok pencarian. Total luas block candidate, selain ditentukan oleh luas area pencarian, juga ditentukan oleh besarnya magnitude. Setelah didapat block matching, maka selisih posisi blok target disebut vektor gerak, proses ini menghasilkan vektor gerak pada arah horizontal MVX dan vektor gerak pada arah vertikal MVY.

\subsection{Matriks Fundamental}

Matriks fundamental $\mathrm{F}$ adalah matriks $3 \times 3$ yang merepresentasikan hubungan geometri. 8point algorithm pertama kali dikembangkan oleh longuest-Hinggins. Merupakan metode yang paling umum digunakan untuk menghitung matriks fundamental dari delapan atau lebih titik titik korespondensi (Ying Zhang et al,2016). Algoritma ini memiliki keunggulan sederhana dan mudah diimplementasikan. Jika $\mathrm{x}=\left[\begin{array}{lll}\mathrm{x} & \mathrm{y} & 1\end{array}\right] \mathrm{T}$ dan $\mathrm{x}{ }^{\prime}=\left[\mathrm{x}^{\prime}\right.$ $\left.\mathrm{y}^{\prime} 1\right] \mathrm{T}$, setiap titik pada $\mathrm{F}$ terdapat persamaan linier. Persamaan ini dapat ditulis sebagai berikut:

$$
\left[x^{\prime} y^{\prime} 1\right]\left[\begin{array}{lll}
f 21 & f 22 & f 23 \\
f 24 & f 25 & f 26 \\
f 27 & f 28 & f 29
\end{array}\right]\left[\begin{array}{l}
x \\
y \\
1
\end{array}\right]=0
$$

Kondisi kamera adalah kamera yang tidak terkalibrasi, sehingga mengalami masalah dalam perhitungan (Uğur et al,2018). Kamera yang digunakan akan menghasilkan urutan gambar (Ying Zhang et al,2016). Untuk mengatasi kendala komputasi citra yang dihasilkan, aljabar fundamental matrix dimana $\mathbf{F}$ merepresentasikan batasan epipolar. Hal tersebut dapat dijelaskan pada gambar pertama, untuk setiap titik m. (Andrew Zisserman, 2013) Titik yang sesuai m' adalah garis epipolar. Begitu juga dengan bidang pada gambar kedua, titik m pada garis $\mathbf{l m}$.

$$
l^{\prime} m=\mathrm{Fm} \text { and } l m=\mathrm{F}^{\mathrm{T}} \mathrm{m}^{\prime}
$$

Untuk posisi $\mathrm{m}$ terletak pada l'm dan $\mathrm{m}$ 'terletak pada $\mathrm{lm}$, hubungan yang didapat dari simbol-simbol tersebut adalah :

$$
\mathrm{m}^{\prime \mathrm{T}} \mathrm{Fm}=0 \text { and } \mathrm{m}^{\mathrm{T}} \mathrm{F}^{\mathrm{T}} \mathrm{m}^{\prime}=0
$$

Bagian yang lain akan dihitung pada F-Matrix, di mana $\mathbf{m}_{\mathbf{i}}=\left[u_{\mathrm{i}}, v_{\mathrm{i}}, 1\right]^{\mathrm{T}}$ and $\boldsymbol{m}_{\boldsymbol{i}}{ }^{\prime}=\left[\mathrm{ui}^{\prime}{ }^{\prime}, \mathrm{vi}{ }^{\prime}\right.$, T.vector depth estimation.

Dibutuhkan transformasi geometrik berdasarkan perpindahan geometrik suatu titik. Transformasi ini terdiri dari translasi, skala dan rotasi. Gambar 4 adalah contoh dari masing-masing transformasi geometrik untuk model 2 dimensi. Diperlukan suatu representasi yang seragam (homogeneous representation) agar memungkinkan dilakukannya transformasi komposit secara efisien dan dapat menyimpan faktor normalisasi koordinat akibat transformasi yang dilakukan berturut-turut. Representasi hogeneous ini biasanya dalam bentuk matriks.

\subsection{Fundamental Matriks Kamera}

Matriks fundamental adalah hubungan antara dua gambar dari pemandangan yang sama yang membatasi di mana proyeksi titik dari pemandangan dapat terjadi di kedua gambar. Mengingat proyeksi titik adegan ke salah satu gambar, titik yang sesuai di gambar lain dibatasi ke garis, membantu pencarian, dan memungkinkan untuk mendeteksi korespondensi yang salah. Matriks fundamental dapat ditentukan dengan sekumpulan titik korespondensi. Selain itu, titik gambar yang sesuai ini dapat ditriangulasi ke titik dunia dengan bantuan 
matriks kamera yang diturunkan langsung dari matriks fundamental ini.

$$
\mathrm{P}=[\mathrm{I} \mid \mathbf{0}] \mathrm{P}^{\prime}=\left[\left[\mathbf{e}^{\prime}\right] \times \mathrm{F}+\mathbf{e}^{\prime} \mathbf{v}^{\mathrm{T}} \mid \lambda \mathbf{e}^{\prime}\right]
$$

Dari rumus diatas akan dihasilkan nilai yang digunakan untuk diproses lebih lanjut. Matriks fundamental mengekspresikan geometri epipolar dalam citra stereo. Fundamental matriks pada kamera stereo digunakan untuk menentukan transformasi proyektif antar frame yang dibandingkan. Rumus untuk kamera stereo dengan bentuk Fundamental matriks menggunakan karakterisasi dari matriks fundamental $\mathrm{F}$ berdasarkan matriks kamera stereo. Berikut rumus untuk matriks kamera stereo menggunakan fundamental matrix (Andrew Zisserman, 2013).

\section{Vector Depth Estimation}

Data penelitian berupa video bayi pasca operasi pada umur lebih dari 1 bulan hingga kurang dari 12 bulan yang memenuhi kriteria inklusi (L. Cattani et al.,2016). Pada fase preprocessing akuisisi objek citra diambil dari dua frame yang berbeda image sequence pada video, sedangkan posisi objek yaitu bayi juga bergerak, sedangkan kamera tidak bergerak, dan pada saat akuisisi citra tidak menggunakan zooming. Sebagai bahan penelitian digunakan dua buah gambar video bayi yang masing-masing memiliki resolusi 640 x 840 dengan tipe AVI. Gambar 2 menunjukkan gambar dari dua frame yang berbeda. Selanjutnya pemilihan titik-titik yang sesuai untuk masing-masing pasangan citra berdasarkan vektor gerak dan vektor gerak X Y, yang nantinya akan digunakan sebagai masukan selanjutnya untuk proses rekonstruksi. Kemudian perhitungan matriks fundamental dengan algoritma delapan titik, yang menyatakan kesesuaian antara citra tampilan pertama dengan citra tampilan kedua berdasarkan motion vector.

Matriks proyeksi kamera diturunkan dari nilai fundamental matrix. Pengujian dilakukan dengan triangulasi untuk menentukan pasangan $\mathrm{M}$ dan $\mathrm{M}^{\prime}$ yang menghasilkan dari rekonstruksi titik 3D dari objek yang ada di depan kamera (Fan Zhou, C. Zhong, and Q. Zheng,2015). Setelah data diperoleh koordinat citra dari titik $\mathrm{x}$ dan $\mathrm{x}$ ', serta matriks proyeksi kamera $\mathrm{M}$ dan $\mathrm{M}^{\prime}$, selanjutnya dilakukan rekonstruksi koordinat 3D dengan menggunakan triangulasi Direct Linear Transformation (DLT). Merupakan algoritma untuk memperkirakan koordinat 3D suatu objek dengan menghitung data koordinat citra pada beberapa gambar yang diambil dari berbagai posisi di sekitar objek. Matriks proyeksi kamera diturunkan dari matriks nilai fundamental (M. Yang, Y. Liu, and Z. You,2011). Pengujian dilakukan dengan triangulasi untuk menentukan pasangan $\mathbf{M}$ dan $\mathbf{M}^{\prime}$ yang menghasilkan rekonstruksi titik 3D dari objek yang ada di depan kamera. Setelah data diperoleh koordinat citra dari titik x dan x ', serta matriks proyeksi kamera $M$ dan M' (Steger,2012), selanjutnya dilakukan rekonstruksi koordinat 3D tersebut dengan menggunakan triangulasi. Algoritma ini digunakan untuk memperkirakan koordinat 3D suatu objek dengan menghitung data koordinat citra pada beberapa gambar yang diambil dari berbagai posisi di sekitar objek.

Beberapa gambar yang dihasilkan, akan direkonstruksi titik-titiknya, hasil ekstrak frame yang nantinya diolah sehingga membentuk 3D dari inputan berupa citra image sequence (seperti terlihat pada Gambar 3) dan dilihat hasilnya dengan pengujian menghitung nilai error. gambar inputan terlihat seperti pada Gambar 3.

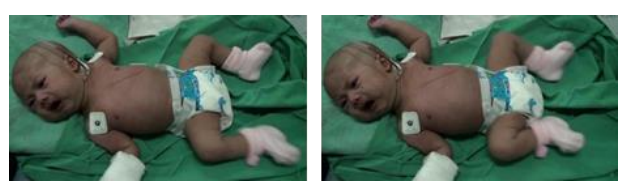

Gambar 3. Gambar dari dua frame yang berbeda

Dari data pada Gambar 3 akan diambil vektor geraknya menggunakan block matching, terlihat pada Gambar 4. Dari data video tersebut dipecah menjadi beberapa frame yang berutan atau image sequence dengan mengambil setiap frame video. Pada Gambar 4 menunjukkan plot garis epipolar antara gambar citra sebelah kana dengan gambar citra seelah kiri dimana keduanya merupakan image sequence dalam satu video, gambar kanan sesuai dengan titik-titik referensi pada gambar frame sebelumnya, yang nampak pada gambar citra sebelah kiri, titik-titik tersebut menggambarkan fitur (ciri khas) yang cocok, dan garis epipolar yang sesuai (Yildirim and H. A. Ilgin,2015)

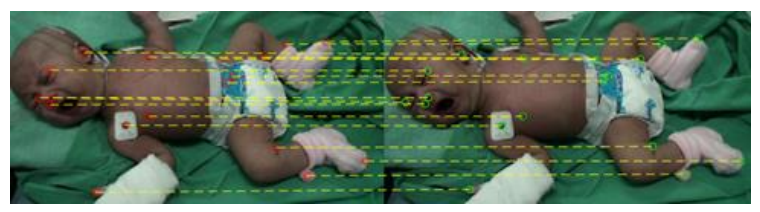

Gambar 4. Pencocokan Image Sequence (Vektor Gerak)

Lingkaran di gambar 4 sisi kiri dan kanan adalah fitur (ciri khas) yang cocok, dan garis dari dua gambar mewakili garis epipolar yang sesuai. Ukuran bingkai pada Gambar 4 adalah 480 x 640 piksel. Setiap frame yang dihasilkan akan dibandingkan dengan frame-frame selanjutnya untuk mendapatkan motion vector menggunakan block matching. Ukuran Pencocokan blok adalah $8 \times 8$ piksel dengan 10 piksel untuk wilayah pencarian. Dari metode vektor ini didapatkan arah sumbu x dan sumbu y dengan ukuran matriks 60 x 80 . 


\section{Hasil dan Pembahasan}

Pada penelitian sebelumnya telah dilakukan penelitian klasifikasi gerakan aktivitas bayi pasca operasi berbasis motion vector (Faisal Lutfi et al.,2017), dengan mengembangkan sistem untuk mengenali FLACC berbasis aktivitas bayi pasca operasi (Wajah, Kaki, Activity, Cry, Consolability), skor 0 diberikan jika bayi bergerak dengan mudah, skor 1 jika bayi menggeliat, dan skor 2 jika bayi menggeliat menyentak dengan mengamati ciri-ciri gerak. Pada FLACC, aktivitas adalah salah satu dari lima parameter untuk mengidentifikasi level sakit bayi. Menggunakan algoritma block matching dengan penambahan deret Taylor untuk menghasilkan nilai dengan sub-piksel akurasi gerakan dari frame acuan terhadap frame setelahnya dalam bentuk vektor gerak. Video telah diverifikasi oleh dokter dan perawat menggunakan hormon kortisol dengan FLACC pengukuran. Hasil percobaan menunjukkan Klasifikasi menggunakan SVM dapat mendeteksi pergerakan aktivitas bayi mudah, menggeliat, dan menyentak sebesar $90,4762 \%$.

Data citra yang digunakan merupakan video pasca operasi pada bayi berumur antara 1 hingga 12 bulan dimana pada rentang umur itu bayi belum bisa menyampaikan secara verbal segala hal yang dirasakan, melainkan dengan tangisan dan gerakan pada tungkainya, data diambil dari dua frame yang berbeda yang ditampilkan pada Gambar 2, Rekaman video dilakukan di bawah pengawasan orang tua. menggunakan kamera digital Sony HDR-XR520 12.0 Mega piksel. Posisi kamera tidak bergerak. Kedua gambar memiliki bagian objek yang sesuai satu sama lain.

Semua data dikumpulkan sebelum dan setelah operasi ketika bayi dalam kondisi non-analgesic. Data rekaman video dinilai oleh dua ahli anestesi pediatrik, yaitu berasal dari RSUD Dr. Soetomo, Surabaya, dan dari Rumah Sakit Kandang Kerbau, Singapura, dalam rangka untuk menghindari subjektivitas. Selanjutnya pemilihan titik-titik yang akan direkonstruksi untuk masing-masing citra didasarkan pada nilai motion vector. Prosesnya adalah menentukan titik gambar pertama yang terkait dengan titik gambar kedua.

Proses penentuan rasio antar titik pada citra pasangan disebut korespondensi. Jika ditemukan titik - titik dari mana bayangan kiri dan kanan, itu disebut pasangan konjugasi atau pasangan terkonjugasi. Cara menentukan pasangan menggunakan besaran nilai pada motion vector. Setelah data posisi koordinat didapatkan pasangan citra, selanjutnya dilakukan komputasi fundamental matrix.

Kami menggunakan input video berukuran 640 x 480, dan dari video ini dilakukan ekstraksi vektor gerak menggunakan block matching 8 × 8, karena penulis telah mencoba beberapa metode lain memiliki kekurangan dalam hal akurasi pengukuran. Kemudian dengan menggunakan algoritma pencocokan blok, untuk mencari kecocokan antara frame saat ini dengan frame referensi, dalam menghitung besarnya vektor gerak menggunakan deret Taylor untuk mendapatkan nilai presisi subpiksel.

Gambar pertama dan gambar kedua seperti terlihat pada Gambar 3 dan Gambar 4 dibandingkan menggunakan matriks fundamental. Matriks fundamental diperoleh dengan menggunakan algoritma delapan titik dengan cara mendapatkan minimal delapan titik pada citra posisi koordinat pada citra pertama yang dipasangkan dengan delapan titik koordinat citra pada citra kedua. Dari hasil perhitungan fundamental matrix diperoleh besaran nilai gerakan, berdasarkan data, tungkai memiliki besaran nilai gerakan yang lebih besar dibanding bagian tubuh lain pada bayi, sehingga data tersebut bisa dilihat pola perbandingan pada kedua citra bayi tersebut, berikut adalah nilai dari fundamental matrix pada Tabel 1 .

\begin{tabular}{|c|c|c|c|}
\hline \multicolumn{4}{|c|}{ ruma } \\
\hline Value & & $I^{\prime}=\mathbf{F x}$ & \\
\hline \multirow{3}{*}{$\mathbf{I}=\mathbf{F T X}$} & $-1,0842 \mathrm{e}-19$ & $3,0249 \mathrm{e}-17$ & $-1,9429 \mathrm{e}-16$ \\
\hline & $-6,1068 \mathrm{e}-17$ & $-8,3182 \mathrm{e}-17$ & $-0,1335$ \\
\hline & $8,5869 \mathrm{e}-16$ & 0,1335 & 1,2018 \\
\hline
\end{tabular}

Selanjutnya dicari persamaan garis epipolar l' = Fx adalah garis epipolar yang bersesuaian dengan $\mathrm{x}$. Sedangkan I = FTX' adalah garis epipolar yang bersesuaian dengan $x^{\prime}$. Sehingga dapat diplotkan garis epipolar yang menggambarkan korespondensi pada kedua citra tersebut.

Kemudian dihitung parameter-parameter yang dibutuhkan untuk proses rekonstruksi seperti yang dijelaskan pada bagian sebelumnya, diperoleh matriks yang akan digunakan sebagai parameter dalam proses rekonstruksi, ditampilkan pada Gambar 5

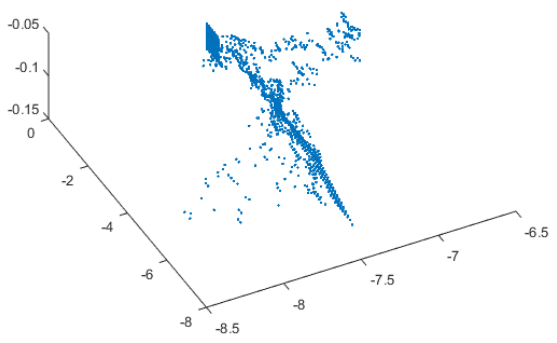

Gambar 5. Hasil fitur magnitude tungkai bayi

Hasil rekontruksi pada gambar 5 menunjukkan besaran gerakan tungkai, baik pada tungkai tangan maupun tungkai pada kaki, hal ini bermanfaat untuk bisa mendapatkan data fitur penciri dan pola besaran gerakan pada bayi, dengan data pola ini berfungsi 
untuk penentuan besaran gerakan untuk mengukur tingkat nyeri bayi pasca operasi dan untuk mengukur kadar obat dalam masa penyembuhannya (Faisal Lutfi et al.,2017).

Apabila telah diperoleh data koordinat citra dari titik x dan x' serta matriks proyeksi kameranya, maka dilakukan rekonstruksi koordinat 3D menggunakan triangulasi, terlihat pada Tabel 2.

Tabel 2. Camera Matrix

\begin{tabular}{|l|l|l|l|l|}
\hline Value & \multicolumn{4}{|c|}{$\mathbf{X}$} \\
\hline \multirow{4}{*}{$\mathbf{x}^{*}}$, & $\begin{array}{l}3,15956 \mathrm{e}- \\
30\end{array}$ & $\begin{array}{l}4,8925 \mathrm{e} \\
-16\end{array}$ & $\begin{array}{l}4,4329 \mathrm{e} \\
-15\end{array}$ & -1 \\
\cline { 2 - 5 } & $\begin{array}{l}8,5869 \mathrm{e}- \\
16\end{array}$ & 0,1335 & 1,2018 & $\begin{array}{l}3,6637 \mathrm{e}- \\
15\end{array}$ \\
\cline { 2 - 5 } & $6,1068 \mathrm{e}-$ & $\begin{array}{l}8,3182 \mathrm{e} \\
-17\end{array}$ & 0,1335 & $\begin{array}{l}2,2204 \mathrm{e}- \\
16\end{array}$ \\
\hline
\end{tabular}

Pengujian dilakukan dengan menghitung nilai residual error pada fundamental matrix dengan hasil yang diperoleh dipengujian adalah $1,82 \times 10^{-07}$. Tungkai bayi dideteksi dengan menggambarkan hasil nilai titik yang ditemukan dengan melakukan proses rekonstruksi pergerakan pada koordinat 3D (Gambar 4).

Hasil nilai rekonstruksi setiap titik-titik pada sampel data dari image sequence dilakukan pengelompokkan berdasarkan besaran magnitude dan besaran nilai motion vector, besaran magnitude dan besaran motion vector inilah yang dijadikan sebagai nilai fitur atau ciri, dimana jika nilai motion bernilai memiliki nilai yang sangat besar dan nilai magnitude sangat tinggi, maka itulah posisi nilai tungkai nya yang akan dijadikan sebagai nilai fiturnya. pergerakan tungkai bayi yang terusmenerus (menggeliat) dan tenang. Cluster dilakukan dengan K-Means. Metode K-means merupakan algoritma untuk pengelompokkan $\mathrm{m}$ objek berdasarkan atribut menjadi $\mathrm{k}$ partisi dimana $\mathrm{k}<\mathrm{m}$ [17]. Proses ini dilakukan dengan menentukan jumlah cluster pada penelitian terdapat 2 cluster. Kemudian menentukan nilai centroid, setelah itu jarak antara titik centroid dengan titik tiap objek dilakukan proses perhitungan. Setelah nilai dari hasil perhitungan diperoleh, setiap anggota kelompok dialokasikan pada distance matrik 0 menunjukkan titik-titik dari sampel data image sequence bayi yang pergerakannya tenang atau 1 menunjukkan titik-titik dari sampel bayi menggeliat. Proses pada langkah ke dua akan diulang sampai nilai centroid tetap dan kelompok data cluster tidak lagi terjadi perpindahan data. Hasil deteksi tungkai bayi pada cluster dapat dilihat pada tabel 3 .

Tabel 3. Cluster Deteksi Tungkai Bayi

\begin{tabular}{|c|c|l|}
\hline Cluster 0 & Cluster 1 & \\
\hline 0 & 23 & Cluster 1 \\
\hline 17 & 7 & Cluster 0 \\
\hline
\end{tabular}

Dari 47 data yang diujikan didapatkan hasil cluster 0 sejumlah 17 dengan presentase 36\%, dan cluster 1 sejumlah 30 dengan presentase $64 \%$. Kemudian data yang tidak sesuai sejumlah 7 dengan presentase Incorrectly clustered instances $14.8936 \%$. Pengujian cluster menunjukkan deteksi tungkai bayi dari hasil rekonstruksi pada sampel data menggeliat lebih sedikit dari pergerakan tenang. Terlihat pada gambar 5 berupa besaran fitur magnitude untuk deteksi tungkai pada bayi pasca operasi.

\section{Kesimpulan}

Berdasarkan hasil percobaan dan hasil yang ditunjukkan pada bagian sebelumnya. Untuk mendapatkan fitur magnitude untuk mendeteksi tungkai pada bayi pasca operasi, berbasis motion vector dan algoritma vector depth estimation menggunakan image sequence pada video dapat dilakukan dengan beberapa langkah: Ekstraksi vektor gerak, menghitung matriks fundamental, menghitung matriks kamera dan rekonstruksi titik 3D berdasarkan nilai $\mathrm{x}$ untuk berpindah ke $\mathrm{x}$ '. Matriks fundamental dapat menentukan kedalaman video dari suatu objek dihitung menggunakan algoritma delapan titik, bahkan tanpa kalibrasi pada kamera, kedalaman video suatu objek citra dapat ditentukan dengan mengekstraksi motion vector, untuk dicari nilai fundamental matrix dan dihitung menggunakan Algoritma 8-point, kemudian dicari nilai camera matrix nya dan yang terakhir menggunakan triangulasi, sehingga dapat di dapat fitur magnitude, bahkan tanpa kalibrasi pada kamera. Hasil titik-titik rekonstruksi dilakukan deteksi tungkai bayi dengan pengelompokkan berdasarkan sampel data yang diambil dari pergerakan bayi yang tenang dan menggeliat. $\mathrm{H}$

Metode ini direkomendasikan karena dapat mendeteksi fitur magnitude dari inputan berupa image sequence dengan menghitung parameter intrinsic sehingga didapat fitur magnitude untuk mendeteksi tungkai pada bayi. Penelitian ini menghasilkan nilai pengujian residual error sebesar $1,82 \times 10^{-07}$. Hasil rekonstruksi dari nilai yang diperoleh dijadikan parameter untuk deteksi tungkai bayi dengan melakukan pengelompokkan (cluster) menggunakan K-Means. Hasil yang diperoleh terdiri dari cluster 0 dan 1 , sebesar $36 \%$ dan $64 \%$ dengan presentase Incorrectly clustered instances $14.8936 \%$.

Untuk selanjutnya, penelitian ini dapat dikembangkan dengan melakukan ekstraksi fitur dengan mendapatkan nilai yang lebih baik dari pergerakan motion vector. Peneliti berencana mengembangkan sistem yang dapat mengklasifikasikan gerakan kaki bayi dari video streaming atau kamera secara real-time. 


\section{Daftar Pustaka:}

Andrej Fogelton and W. Benesova. (2016) : Eye blink detection based on motion vectors analysis, Comput. Vis. Image Underst., vol. 148, pp. 23-33, 2016.

Andrew Zisserman. (2013) : Multiple View Geometry, vol. 53, no. 9.

David P. Snow. (2017) : Gesture and intonation of infant communication: Evidence from regression patterns of language development, Lang. Commun., vol. 59, pp. 180-191, 2017.

Eko Mulyanto, M. Hariadi, and M. H. Purnomo, "Point Cloud Registration for a NonDeformable," vol. 51, no. 3, pp. 506-514, 2013.

Faisal Lutfi, E. M. Yuniarno, and M. H. Purnomo, "A Novel Approach on Classification of Infant Activity Post Surgery Based on Motion Vector," pp. 213-218, 2017.

Fan Zhou, C. Zhong, and Q. Zheng, "Method for fundamental matrix estimation combined with feature lines" Neurocomputing, vol. 160, 2015.

Hannah. F. Rasmussen et al., "Mother-child language style matching predicts children's and mothers' emotion reactivity" Behav. Brain Res., pp. 1-11, 2016.

Hernández-González, R. M. Hidalgo-Aguirre, M. A. Guevara, M. Pérez-Hernández, and C. Amezcua-Gutiérrez, "Observing videos of a baby crying or smiling induces similar, but not identical, electroencephalographic responses in biological and adoptive mothers," Infant Behav. Dev., vol. 42, pp. 1-10, 2016.

Hina Simonnet et al., "Parents behavior in response to infant crying: Abusive head trauma education" Child Abus. Negl., vol. 38, no. 12, pp. 1914-1922, 2014.

Juli Rejito, "Pengklasteran K-Means Database Citra Untuk Meningkatkan Akurasi Pencarian Query CBIR Menggunakan Intensitas Warna” Jurnal Matematika Integratif., vol. 9, pp. 91107,2013 .

Luca Cattani et al., “Author's Accepted Manuscript Monitoring Infants by Automatic Video Processing: A Unified Approach to Motion Analysis" Comput. Biol. Med., vol. 80, no. August 2016, pp. 158-165, 2016.

Menglong Yang, Y. Liu, and Z. You, "Estimating the fundamental matrix based on least absolute deviation" Neurocomputing, vol. 74, no. 17 , pp. 3638-3645, 2011.

Steger, "Estimating the fundamental matrix under pure translation and radial distortion," ISPRS J. Photogramm. Remote Sens., vol. 74, pp. 202217, 2012.
Tongyang Sun et al., "Development of Lower Limb Motion Detection Based on LPMS" 2016.

Uğur, Topay, Tola, Engin, and A. Aydın, "Solving Fundamental Matrix for Uncalibrated Scene," Engineering. 2018

Ying Zhang, L. Zhang, C. Sun, and G. Zhang, "Fundamental Matrix Estimation Based on Improved Genetic Algorithm" 2016 8th Int. Conf. Intell. Human-Machine Syst. Cybern., no. 3, pp. 326-329, 2016.

Yildirim dan H. A. Ilgin, "Motion vector outlier removal using dissimilarity measure" Digit. Signal Process. A Rev. J., vol. 46, pp. 1-9, 2015. 
Volume 7, Edisi 3, Mei 2021

$\mathbf{4 2} \mid \mathrm{H}$ a 1 a $\mathrm{m}$ a $\mathrm{n}$ 